\title{
Tourism, local pride, and attitudes towards the reintroduction of a large predator, the jaguar Panthera onca in Corrientes, Argentina
}

\author{
Flavia Caruso ${ }^{1}$, Ignacio Jiménez Pérez ${ }^{2, *}$ \\ ${ }^{1}$ Facultad de Ciencias Exactas y Naturales y Agrimensura, Universidad Nacional del Nordeste, CP 3400, Corrientes, Argentina \\ ${ }^{2}$ The Conservation Land Trust Argentina, Scalabrini Ortiz $33554^{\circ} \mathrm{J}, \mathrm{CP} 1425$, Buenos Aires, Argentina
}

\begin{abstract}
Few studies have assessed public attitudes in relation to the reintroduction of large felids. We evaluated the knowledge and attitudes of inhabitants of Corrientes province, Argentina, in relation to the proposed reintroduction of jaguars Panthera onca to Iberá Natural Reserve (INR). Corrientes is a traditional society in which cattle ranching shapes much of the geographical landscape and social character. A questionnaire was distributed to a random sample of residents from the provincial capital, 2 towns neighboring INR, and 3 villages inside or adjacent to the reserve. In general, residents showed a much greater positive disposition towards jaguars than actual knowledge about the species. We found a $95 \%$ level of support for the return of jaguars, which was independent of the respondents' gender, age, or location. A small random sample of cattle ranchers also showed significant support for the project. These results were obtained prior to any educational campaigns promoting the reintroduction of jaguars, which suggests that jaguars were already considered a positive symbol in the province. We propose that the jaguar may be acting as a bridge between a proud traditional heritage and an alternative future where ecotourism serves as a route towards economic development. Conservation managers should be aware that this widespread support will probably change once jaguars become present in the local ecosystem and economy.
\end{abstract}

KEY WORDS: Jaguar $\cdot$ Reintroduction $\cdot$ Attitudes $\cdot$ Knowledge $\cdot$ Stakeholders $\cdot$ Cattle ranching $\cdot$ Iberá · Argentina

Resale or republication not permitted without written consent of the publisher

\section{INTRODUCTION}

Large carnivores have traditionally been persecuted by humans, based on the belief or practical experience that they can kill people, livestock, or other domestic animals (Kruuk 2002). The jaguar Panthera onca is the largest terrestrial predator in the Neotropics, where it has been extirpated from $54 \%$ of its original range, and is globally classified by the IUCN as Near Threatened (Caso et al. 2012). Jaguar distribution in Argentina has experienced a $95 \%$ reduction over the last centuries, and the species is presently found in 3 disjunct populations within the Yungas, Chaco, and Atlantic Forest ecoregions in the north- ern part of the country (Di Bitetti et al. in press). Di Bitetti et al. (in press) estimated that around 200 jaguars live in all of Argentina, where the species is formally classified as endangered (Díaz \& Ojeda 2000).

The Iberá Natural Reserve (INR) comprises a 1.3 million ha ecoregion located between Chaco and the Atlantic Forest that was inhabited by jaguars until the mid-20th century (Parera 2004, Chebez 2008). In an area where the aboriginal Guarani language and traditions are very much alive, the jaguar, or yaguareté as it is called in this language, is still a common character in folk music (chamamé), local names, and legends. Recently, a group of scientists and managers 
(Parera 2004) proposed the restoration of all large mammal species that had become extinct inside INR, including the jaguar. As a response to this proposal, The Conservation Land Trust (CLT) began buying land inside INR in order to establish Argentina's largest national park, and to restore all species of extirpated large mammals (see www.proyectoibera. org). Thus, for the last $5 \mathrm{yr}$, CLT has been reintroducing giant anteaters Myrmecophaga tridactyla and pampas deer Ozotoceros bezoarticus into INR, and in 2010 it publicly announced its intention to reintroduce jaguars to the region (Jiménez 2010, 2011; www.proyectoibera.org).

The reintroduction of large charismatic predators tends to incite more controversy and potential conflict than the reintroduction of other animal species (Hayward \& Somers 2009). In many cases, these initiatives create highly polarized arguments and positions between defenders of large predators and their opponents. Hence, many authors have proposed that significant public support should be a prerequisite for any reintroduction project, especially for those involving large carnivores (Kleiman et al. 1994, Jiménez Pérez 1996, Reading \& Clark 1996, Macdonald 2009). This was explicitly stated by Kelly \& Silver (2009) in a review of potential jaguar reintroductions, and was considered the key component for the successful reintroduction of grey wolves in Yellowstone National Park, USA (Smith \& Bangs 2009).

Our goal was to assess the knowledge and attitudes of the people in Corrientes province in regard to jaguars and their reintroduction to INR. We also wanted to assess the effect of geographical and social differences among Correntinos (i.e. residents of Corrientes) on these human values related to jaguars. The use of the Corrientes province as a study area is based on the fact that the Argentinean Constitution gives authority for wildlife management and conservation to the provinces.

\section{MATERIALS AND METHODS}

\section{Study area}

Corrientes province is located in north-eastern Argentina, and covers $88886 \mathrm{~km}^{2}$ with an estimated population of 993388 (DEyC 2011; Fig. 1). Although at present cattle ranching plays a secondary role in the economy of Corrientes, it still defines much of the physical landscape and cultural identity by occupying around $80 \%$ of its surface (EGES 2009). This province represents one of the oldest traditions of European colonization in the Southern Cone, starting in the 16th century in connection with the Jesuit missions administered from what is currently Asunción in Paraguay (Crow 1992, Foschiatti del Dell'Orto \& Bolsi 1993). When the Jesuits left, the region's culture was characterised by 4 main traits which still define rural Correntino culture today: (1) the use of the aboriginal Guarani language by most rural people, (2) the presence of a highly hierarchical rural society made up of landowners managing large cattle ranches (estancias) through poorly educated cowboys (gauchos), (3) the existence of a rich local folklore expressed through music, legends, fiestas, and religious rituals, and (4) the pervasiveness of traditional conservative values guiding political and economic life (Mantilla 1972). Recently, Corrientes has developed a more modern urban and rural economy based on trade, public jobs, tourism, intensive agriculture, and forestry plantations (EGES 2009, DEyC 2011). With around $20 \%$ of its population living below the poverty rate, Corrientes is among the poorest provinces in Argentina (DEyC 2011).

INR is in the central northern part of Corrientes province, where it protects a 1.3 million ha hydrological basin covered by subtropical wetlands, grasslands, open savannas, and small forests (CLT 2006, Fig. 1). Flooded areas make up the core of INR

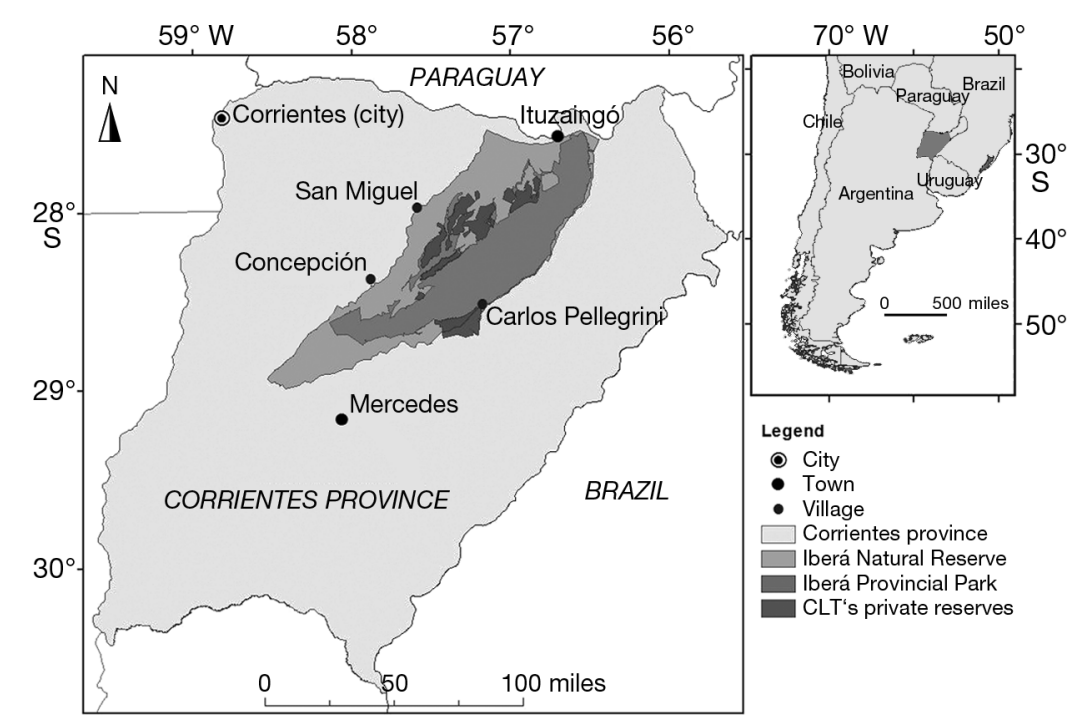

Fig. 1. Study area, showing Corrientes province in relation to Argentina and neighboring countries, the 6 locations where interviews were carried out, and protected areas within Iberá Natural Reserve. CLT: The Conservation Land Trust. 500 miles $=$ ca. $800 \mathrm{~km}$ 
(553000 ha), which belongs to the Government of Corrientes and has been declared a Provincial Park, a highly restrictive kind of protected area (Jiménez Pérez \& Heinonen 2011). The remaining $60 \%$ of INR comprises private properties with temporal or almost no flooding at all. More than $88 \%$ of the surface of these private properties is used for cattle ranching, with rice and forest plantations occupying the remaining 1 and $10.4 \%$, respectively (M. Srur pers. comm.). In 1999, CLT began buying private lands in the area, where it presently owns 150000 ha in INR. These lands are managed as strict conservation areas, which has resulted in a sharp decrease in cattle density and the related use of anthropogenic fires, the reappearance of tall grasslands, and a significant increase in wildlife populations (Jiménez Pérez \& Heinonen 2011). Iberá has become a well known national and international destination for wildlife tourism. Within INR, Colonia Carlos Pellegrini (see below) stands out as the main ecotourist destination.

Three types of locations were chosen to assess the knowledge and attitudes of Correntinos regarding jaguars and their proposed reintroduction. The first type is represented by Corrientes city, the capital of the province and also its largest urban center. The second group is made up of medium-sized towns (Mercedes and Ituzaingó) that are close to INR and have strong cultural and economic ties with this reserve. The last group represents small villages that are inside or adjacent to INR, including Colonia Carlos Pellegrini (hereafter Pellegrini), San Miguel, and Concepción de Yaguareté Corá (hereafter Concepción; see Fig. 1 for the relative positions of these locations). Inhabitants of these villages would have the highest chances of sharing space with a population of reintroduced jaguars.

Corrientes city harbors a population of 317000 people engaged mostly in the public sector, trade, agro-industry, and university studies (DEyC 2011). Mercedes is a highly conservative town and administrative center, whose 30000 inhabitants are employed in public offices, trade, cattle ranching, rice crops, and, more recently, tourism (DEyC 2011). Ituizaingó, with 19000 people, shows a less conservative character than Mercedes due to the influence of the city of Posadas, in neighboring Misiones Province (DEyC 2011). Compared to Mercedes, its economy is more dependent upon non-traditional activities, such as tourism and forestry. Pellegrini, with ca. 700 people, is the only village that lies inside INR. Because of this, what used to be a local economy based on subsistence hunting and temporary jobs in agriculture and cattle ranching until the 1980s, has recently changed into an ecotourism-based economy. San Miguel and Concepción (10700 and 5200 inhabitants, respectively) are both adjacent to INR and maintain an economy based mostly on cattle ranching and forestry. Tourism has not become a significant activity in these 2 villages, but their authorities, local organizations, and entrepreneurs have identified it as a priority option for economic development.

\section{Sociological survey}

A structured questionnaire in Spanish was used in face-to-face interviews during October to December 2010 with 446 randomly selected men and women representing different households from the 5 locations described above. In Corrientes city, interviews were carried out in the local Costanera, or promenade, where inhabitants from all social classes typically come to walk. In Ituzaingó, Mercedes, San Miguel, and Concepción, interviews were carried out in a similar manner around their central plazas. In the case of Pellegrini, where people tend to stay mostly at home, interviews were carried out through a doorto-door systematic sample of households.

Each interview started with the researcher showing a photograph of a jaguar to the interviewee, in order to check correct identification of the species (Box 1). Following this, a series of socio-economic questions concerning the origin, age, sex, education, and occupation of the respondents and their knowledge and attitudes towards jaguars were asked. The last question was related to their attitude towards jaguar reintroduction to INR (Box 1). For our study, we defined attitude as a 'person's evaluation, either favorable or unfavorable, of a person, object, concept, or action' (Pierce et al. 2001). In our case, we assessed both attitudes towards jaguars and their reintroduction to Iberá.

The number of interviews for each location was grossly related to the respective population size: 136 in Corrientes city, 100 in Mercedes, 100 in Ituzaingó, 40 in Concepción, 40 in San Miguel, and 30 in Pellegrini. Trial tests with 2 external evaluators were carried out to verify the clarity of the questions and neutral influence by the interviewer.

Because no cattle ranchers were found during these randomized surveys, we carried out a second, nonrandom survey focused on ranch owners and administrators from Mercedes. We chose this group and location because Mercedes is the hub of the strongest anti-environmentalist organization (Fundación Iberá Patrimonio de los Correntinos) in the region, and therefore we expected to find the greatest opposition 
Box 1. Questionnaire used in the survey on perceptions and knowledge of Correntinos about jaguars and their reintroduction to Iberá National Reserve, Corrientes, Argentina, 2010
1. Age
2. Place of birth
3. Place of residence
4. Gender
5. Occupation: (a) Cattle ranching, (b) Agriculture, (c) Trade, (d) Tourism, (e) Government employee, (f) Other
6. Education level: (a) Primary school unfinished, (b) Primary education, (c) High school, (d) University degree
7. How long have you been living in this location?

\section{Basic knowledge on the species}

The interviewer shows a picture of a jaguar to the interviewee.

8. Did the person identify the species correctly after seeing it in a photograph? (a) Yes (b) No

9. Do jaguars live in Corrientes? (a) They never lived in the province. (b) They used to live in the province but became extinct here. (c) They are still living in the province.

10. If Question 9 was answered 'c,' then: Where do you think you could see jaguars in Corrientes?

11. Jaguars tend to kill and eat people? (a) Yes (b) No

12. Jaguars play a key ecological role in the natural landscapes of Iberá by keeping in check their wild prey. (a) Agree (b) Disagree (c) Indifferent

\section{Attitudes and perceptions}

13. What is the first thing that comes to your mind when thinking of these animals?

14. Jaguars could become an important tourist attraction for visitors to Iberá, which could improve local people's income. (a) Agree (b) Disagree (c) Indifferent

15. Jaguars are beautiful animals that bring beauty to natural landscapes in Corrientes province. (a) Agree (b) Disagree (c) Indifferent

16. Some scientists are recommending the reintroduction of jaguars to Iberá, so they can return to this nature reserve where they used to live during the last century. How do you feel about this? (a) Agree (b) Disagree (c) Indifferent

17. Could you explain the main reasons for your answer?

to jaguar reintroduction from this subsample. Interviewees who had lived in any of the sampled locations for less than $5 \mathrm{yr}$ were not considered as residents, and were therefore excluded from the analysis.

In the case of attitudinal questions (nos. 13 to 17 in Box 1), we excluded instances in which the interviewee could not express a clear response towards the question. Hence, sample sizes for related analyses varied depending on the number of excluded cases.

In order to measure knowledge about jaguars, we created a combined index based upon 4 questions: (1) ability to recognize a jaguar in a photograph, (2) knowledge about the current status of the species in Corrientes, (3) knowledge about jaguars' key ecological role in the ecosystem, and (4) unsustained belief in the jaguars' habit to prey on humans (questions 8 , 9, 11, and 12 in Box 1). Because these questions are related to factual data, we were able to establish a correct answer for each one as an indicator of knowledge. Thus, the data were binary ( 1 for correct, and 0 for incorrect and 'don't know' answers) and when adding these values for the 4 variables, the resulting knowledge index ranged from 0 to 4 , depending on the number of correct answers given by any interviewee. Significant relationships between categorical variables were tested through $R \times C$ tests of inde- pendence using G-tests (Sokal \& Rohlf 2000). In specific cases when more than $20 \%$ of the cells had expected frequencies below 5, we used the FisherFreeman-Halton exact test. Finally, when age was used as the explanatory variable, logistic regressions were applied.

\section{RESULTS}

After excluding short-term residents, we analyzed 433 interviews from Corrientes city (114), Mercedes (111), Ituzaingó (100), Concepción (40), San Miguel (40), and Pellegrini (28). Table 1 summarizes the general knowledge and opinions of Correntinos regarding jaguars. In general, Correntinos showed a much better attitude towards jaguars than actual knowledge about the species.

Relatively more men $(57 \%, \mathrm{n}=184)$ identified the species after seeing a photograph than women $(36 \%$, $\mathrm{n}=248 ; G=17.8, \mathrm{df}=2, \mathrm{p}<0.0001)$. People with only a high school education tended to identify the animal on a photo better than those that only had a primary education or than those with a university degree (total $\mathrm{n}=432, G=11.7, \mathrm{df}=2, \mathrm{p}=0.003$ ). Most people living in the capital did not recognize the animal, 
while most rural inhabitants tended to identify the species correctly $(\mathrm{n}=433$, $G=37.9$, df $=2$, p $<0.001$, Fig. 2a). When asked about the feelings elicited by the jaguar photo, $85 \%$ of the interviewees recalled feelings of beauty or affection, while the remaining $15 \%$ admitted feelings of fear or aggressiveness.

People with primary $(48.4 \%, \mathrm{n}=95)$ and high school $(46.2 \%, \mathrm{n}=275)$ education tended to know the correct status of the jaguar in Corrientes (i.e.
Table 1. Summary of general knowledge and opinions of Correntinos $(n=433)$ regarding jaguars. INR: Iberá Natural Reserve

Knowledge or attitude variable Response (\%)

Positive identification of jaguar after seeing a photograph $\quad 52$

Correct knowledge of actual status of the species

(i.e. historically present but now extinct in Iberá) 44

Knowledge that jaguars do not prey on people 59

Knowledge about the key ecological role of jaguars 95

Recognition of jaguars as a potential tourist attraction 98

Recognition of jaguars as sources of beauty in natural 99

landscapes of Corrientes

Supportive of jaguar reintroduction to INR

52
44
59
95
98
99

95
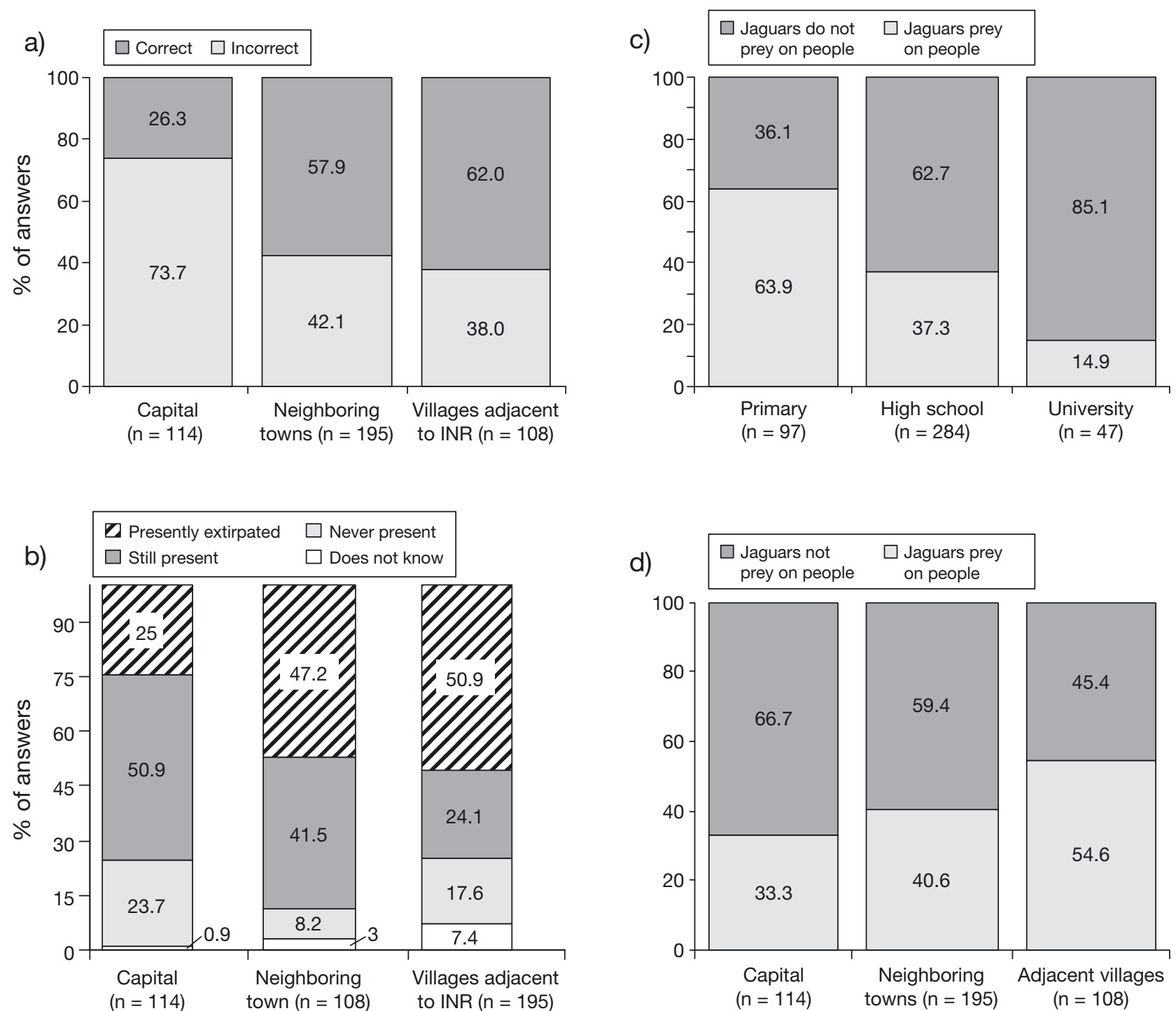

Fig. 2. Social factors that explain differences in knowledge about jaguars in people from Corrientes province: (a) relationship between proximity to Iberá Natural Reserve (INR) and the ability to recognize a jaguar in a photograph, (b) relationship between proximity to INR and knowledge of the population status of the species in the province, (c) relationship between education level and the belief that jaguars prey on people, (d) relationship between proximity to INR and the belief that jaguars prey on people 
extirpated but historically present at Iberá) better than those that had a university degree $(34 \%, \mathrm{n}=47)$ $(G=12.3, \mathrm{df}=4, \mathrm{p}=0.01)$. People living in the vicinity of INR $(50.9 \%, \mathrm{n}=108)$ and neighboring towns $(47.2 \%, n=195)$ were also more aware of the fact that jaguars used to live in the area and had become locally extinct than were inhabitants of the capital (25\%, $\mathrm{n}=114 ; G=43.4 ; \mathrm{df}=6, \mathrm{p}<0.001$, Fig. $2 \mathrm{~b})$.

More women $(64 \%, \mathrm{n}=245)$ than men $(43 \%$, $\mathrm{n}=183$ ) tended to believe that jaguars were 'fierce animals that preyed on people' $(G=3.83$, df $=1$, $\mathrm{p}=0.05)$. There was also a strong inverse relationship between formal education level and the belief that jaguars prey on people $(\mathrm{n}=428, G=37.4$, $\mathrm{df}=2$, $\mathrm{p}<0.001$; Fig. 2c). Also, with increased distance from INR, fewer people believed that jaguars prey on people (n=417, $G=10.7$, df = 2, p < 0.001; Fig. 2d).
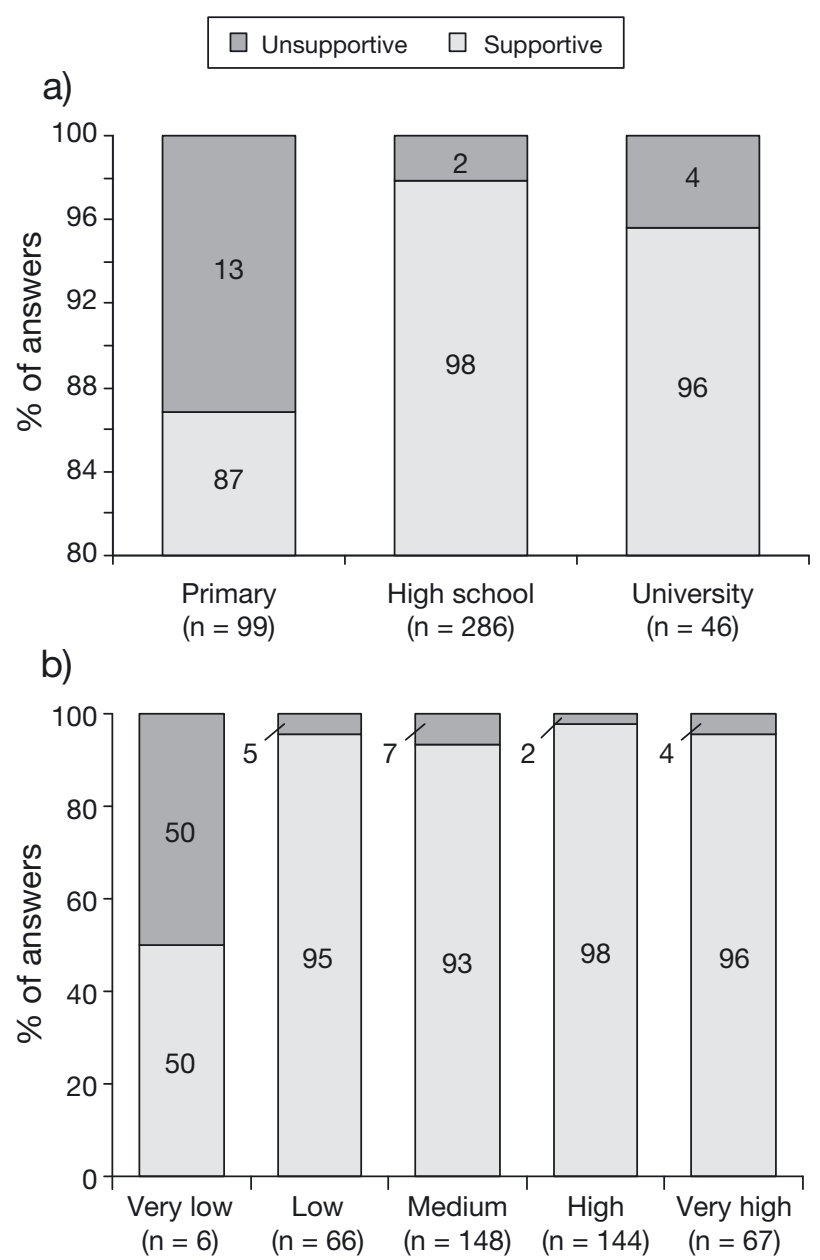

Fig. 3. Significant factors that explain different levels of support shown by Correntinos for the reintroduction of jaguars to Iberá Natural Reserve: (a) level of education, (b) level of knowledge (very low to very high) about jaguars in the province
Even though over $90 \%$ of the people were aware of the ecological role of jaguars, this knowledge was especially high $(100 \%, \mathrm{n}=47)$ in interviewees with a university education (total $\mathrm{n}=432, G=11.4$, $\mathrm{df}=4$, $\mathrm{p}=0.02$ ). Also, more people living in villages inside or adjacent to INR and people living in the capital recognized this ecological role than people living in neighboring towns ( $\mathrm{n}=417, G=10.5$, $\mathrm{df}=4, \mathrm{p}=0.03$ ). There was also an inverse relationship between age of the interviewee and their belief that jaguars could serve as a tourist attraction (logistic regression, $\mathrm{n}=427$, $\chi^{2}=6.87, \mathrm{df}=1, \mathrm{p}=0.0088$ ). However, the majority of old people still think that jaguars could serve as a tourist attraction. An inverse prediction based on the logistic regression model indicates that the probability that a person believes that jaguars could serve as a tourist attraction is $95 \%$ at age 48 and diminishes to $90 \%$ at age 67 and to $80 \%$ at age 88 .

Jaguar reintroduction was supported by $95 \%$ of the interviewees. Such support was not related to the respondents' gender, age, or location. However, people with only primary education showed a lower level of support (i.e. $87 \%, \mathrm{n}=99$ ) than the other groups with higher education $(\mathrm{n}=431, G=13.4$, $\mathrm{df}=2, \mathrm{p}=0.001$; Fig. 3a). When we compared the non-random subsample of cattle ranchers $(n=15)$ with the interviewees employed in other trades, the former showed a lower level of support for jaguar reintroduction, even though $68 \%$ of them still favored its return to INR ( $\mathrm{n}=431, G=12.9, \mathrm{df}=5, \mathrm{p}=0.02$ ). Finally, there was no clear relationship between knowledge of the species and support for its reintroduction. Only a very small group with a very low level of knowledge $(n=6)$ was significantly less supportive than the other 4 knowledge groups on this subject (Fisher's exact test for count data, $p=0.002$, Fig. 3b).

When asked for the main reason for their support of the reintroduction, $44 \%$ of interviewees cited its touristic appeal, 25\% said that it was part of their provincial heritage, $16 \%$ declared that it enhanced the beauty of Iberá, and 15\% highlighted its ecological role in the reserve. On the other hand, $77 \%$ of the people that were against the reintroduction justified this based on the belief that jaguars prey on people, while the other $23 \%$ used its habit of preying on cattle as an explanation.

\section{DISCUSSION}

There seems to be a discrepancy between factual knowledge about jaguars in Corrientes province and widespread support for the species' reintroduction. A 
significant proportion (48\%) of Correntinos did not recognize the species from a photograph, and $56 \%$ did not know its actual status as a historically extant but currently extirpated species. Other authors have found a similar disparity between knowledge and attitudes in the case of biodiversity conservation (e.g. Kellert 1996, Kellert et al. 1996, Pierce et al. 2001, Johns 2009).

Several patterns found in this study match findings from similar studies. For instance, women have less factual knowledge of wildlife than men, and they also tend to show more fear of large carnivores (Kleiven et al. 2004). People living in the vicinity of large carnivores tend to fear their potential role as 'man-eaters' more than people living in neighboring towns or the capital, but they also have a better understanding of their actual population status (Kellert et al. 1996, Kleiven et al. 2004, Dos Santos et al. 2008). It is also typical that urbanites and people with a university education tend to see the key ecological role of large carnivores as top predators more readily than do other groups (Kellert et al. 1996, Kaltenborn et al. 1998). However, it is rarer that people living in small villages adjacent to the park also recognize the ecological role of jaguars more than inhabitants of larger neighboring towns. This could suggest that people living just adjacent to the reserve or in the capital have a higher level of identification with conservation values related to INR compared with inhabitants from neighboring towns, who may see conservation as being in opposition to their traditional agronomic values.

People in Corrientes seem to be highly enthusiastic (95\% level of support) about the return of jaguars to INR. Surprisingly, and in contrast to other studies on attitudes towards large carnivores (e.g. Kellert et al. 1996, Williams et al. 2002, Blanco \& Cortés 2002), this high level of support for jaguar reintroduction was not affected by the respondents' gender, age, or proximity to potentially reintroduced animals.

It is difficult to compare this level of support with similar cases in other regions since we could not find another assessment of attitudes prior to the reintroduction of a large felid. The case that has been most studied in this regard is the reintroduction of wolves. Williams et al. (2002) carried out a comprehensive review of studies assessing attitudes towards wolf reintroduction in different countries. They found that only in $5 \%$ of 23 studies, did $91 \%$ or more of the respondents show support for wolf restoration. Gusset et al. (2008) interviewed people living in the vicinities of Hluhluwe-iMfolozi Park, South Africa, about their attitudes towards the reintroduction of wild dogs. They found $60.7 \%$ of positive responses in
2000 , which decreased to $38.6 \% 4$ yr later, as interactions with wild dogs outside the reserve became more common. Zeiler et al. (1999) interviewed inhabitants of Vienna, Austria, about their attitudes towards the reintroduction of large carnivores (brown bear and European lynx) and found a 70\% level of support, which was significantly lower than support for other species of wildlife.

Other researchers have assessed attitudes of local people regarding the conservation of preexisting jaguar populations. Paviolo (2010) found that $88 \%$ of people living in the vicinity of jaguars in the neighboring province of Misiones, Argentina, supported its conservation. Dos Santos et al. (2008) discovered that a significant majority $(85.5 \%)$ of Brazilians from 5 biomes thought that jaguars should not be eliminated.

Much has been said about the conflict between large carnivores like jaguars like jaguars and cattle (Medellín et al. 2002, Crawshaw 2004, Rabinowitz 2005, Kelly \& Silver 2009). Zimmermann et al. (2005) found that more than half $(64 \%)$ the cattle ranchers in the Pantanal of Brazil could not tolerate jaguars on their ranches, even though $74 \%$ felt that these cats deserved protection. Conforti \& Cascelli de Azevedo (2003) identified a $63.5 \%$ level of support for jaguar permanence in Iguazú National Park (Brazil) from local livestock owners. In interviews conducted with herdsmen living in areas used by snow leopards, Oli et al. (1994) found that $52 \%$ saw the total eradication of leopards as 'the only remedy worth considering,' and an additional $35.3 \%$ believed that 'eradication should be attempted first and compensation schemes implemented only if this failed.' In this context, a $68 \%$ level of support from cattle ranchers towards jaguar reintroduction in Iberá seems to be quite positive compared to other regions where large felids and cattle coexist. However, the number of cattle ranchers that support such an initiative could likely change once jaguars start interacting with cattle.

Our quantitative results are supported by complementary qualitative data. After the study was carried out, CLT started a provincial campaign with stickers and posters using a large jaguar photograph with the phrase 'Corrientes vuelve a ser Corrientes' ('Corrientes returns to being Corrientes'). As a result of this campaign, CLT staff were surprised to receive messages of support and positive excitement about the idea. Most strikingly, several of these messages came from cattle ranchers and provincial government officials or politicians. What might be even more significant is the pervasive silence about this issue from Iberá Patrimonio de los Correntinos, a local anti-envi- 
ronmentalist organization led mainly by cattle ranchers and wealthy farmers, who own TV and radio programs and have been extremely vocal in their anticonservation messages. With this quantitative and qualitative information in hand, CLT decided to halt the campaign since there seemed to be little room for improvement in attitudes towards jaguar reintroduction.

Perceptions and attitudes are highly contextual and dynamic, depending not only on the species but on the specific geographical, ecological, and cultural setting, plus its conservation story, especially in the case of reintroductions. The relevance of differences in context was highlighted by a comparative study on attitudes towards jaguars in different regions within Brazil (Dos Santos et al. 2008, Marchini \& Macdonald 2012). Similarly, Maji \& Bath (2010) showed how attitudes towards wolf conservation are affected by space and time within the same country.

At a certain point, minority groups can become very vocal and create a vivid climate of confrontation around the presence of large predators. This seems to be the case for wolf reintroduction in the greater Yellowstone ecosystem, where years of wolf presence in the region have not helped to mitigate a conflict that is very much alive in the public arena (Smith \& Bangs 2009). More than $20 \mathrm{yr}$ after the release of the first wolf pack in the area, cattle ranchers and some conservative anti-government groups are actively promoting the removal of this predator, while some environmentalists actively show their discomfort towards wolves being killed outside protected areas (e.g. http://cryingwolfmovie.com/).

On the other hand, the reintroduction of brown bears in the Pyrenees stands out as an example where the level of conflict has decreased sharply since the first animals were released in 1996. At that time there was significant opposition towards this initiative (Palazón-Miñano et al. 2011). Thus, when in 2008, 1 of these animals attacked a hunter in the Spanish Pyrenees, at least 6 newspapers and radio programs in Catalonia conducted surveys on what people thought about bear reintroduction in the region. All the surveys showed more than $70 \%$ support for the initiative, which was higher than the level of suport at the beginning of the reintroduction program (J. Ruiz-Olmo unpublished data). Even more noteworthy is that after this incident, the local associations of cattle ranchers, who had been highly vocal in their opposition to bear reintroduction in the late 1990s, did not participate in any debate or complaint supporting the withdrawal of local bears, including the specific individual that harmed the hunter. Seeing this, it would be advisable to carry out a before-and-after-impact-control study that measures changes in attitudes after jaguars return to Iberá.

A key question is why the Correntinos showed such widespread enthusiasm for the return of this large predator, an enthusiasm that was not affected by gender, age, or location, and was only mildly tempered by differences in education level and occupation. This is especially puzzling in a society that has a very poor tradition of conservation agencies or environmental groups, and that has also caused the largest extinction of large mammals in northern Argentina during the 20th century (Parera 2004). It is also especially puzzling in a province that has traditionally seen itself as a cattle-ranching society.

One possible explanation may come from linguistics. As mentioned, the rural Correntinos use aboriginal Guarani as their main language. Thus being able to speak Guarani fluently is still seen as proof of true local character and integration. The word 'jaguar' derives from the Guarani term 'yaguareté' (Chebez 2008), which is what this species is called throughout Argentina. Therefore, the name of the animal connects directly with Corrientes' deeper linguistic and cultural roots.

There are also 2 relevant phrases by which Correntinos define themselves and are defined by other Argentineans: 'Corrientes es una república aparte' ('Corrientes is its own republic') and 'Si Argentina va a la Guerra, Corrientes la ayudará' ('If Argentina goes to war, Corrientes will help her'). These 2 selfdefining phrases underline the isolationist character of a self-referring society that does not feel that it has to follow what the rest of Argentina does, and they also highlight the bellicose character of the Correntinos, who would be happy to support the larger, but intrinsically different, mother-nation in case of war.

Thus, Correntinos may consider the jaguar as a powerful metaphor of their own character because it is Guarani, and therefore authentic, and it is also aggressive and 'guerrero' (warrior-like), as are the Correntinos themselves. This hypothesis was supported by individual conversations with cattle ranchers and government officials who pointed out the jaguar image on a poster and proudly said: 'This animal really represents the true Correntino character and its braveness.'

The previous explanation connects the jaguar with cultural roots that are related to Corrientes' past. This would explain why $25 \%$ of the interviewees who supported jaguar reintroduction used their provincial heritage as the main explanation. There might be a complementary reason for such support that is not related to the past, but rather to the future. Thus, $44 \%$ of 
interviewees cited the tourist appeal of jaguars as the main reason for their support of its reintroduction. This makes sense in a society that sees itself as one of the poorest in Argentina and that is searching for alternative venues for economic development. Within this framework, tourism is presently becoming one of the fastest-growing industries in the province, and Iberá is becoming a major ecotourist destination nationally and internationally. Hence, in this context, the jaguar and its tourist appeal may be seen as a tool for the development of this province. Direct economic benefits have been found to explain tolerance for large carnivores in different regions (e.g. Maji et al. 2011, Lindsey et al. 2013). This is supported by public support for the return of the jaguar from several major communities surrounding INR, since they see this felid as an additional attraction to the eco-tourism industry that they are trying to promote locally.

\section{CONCLUSIONS}

Formal assessments of public attitudes have been widely recommended as a prerequisite for the reintroduction of large carnivores (Clark 2009, Macdonald 2009). However, to our knowledge, this is the first assessment of this kind carried out prior to the reintroduction of a large cat. There seems to be wide support from Correntinos of all ages, gender, and locations towards the return of the jaguar to INR. It is noteworthy that this positive attitude does not come as a result of any formal campaign promoting the return of the species. Hence, it looks like jaguars were already positioned as a positive theme for Correntinos, independently of any attempt to restore the species.

We propose that this widespread support may be explained by jaguars acting as a symbolic bridge that connects a proud provincial heritage based on preHispanic roots with an alternative future based on wildlife tourism, an activity that could allow for economic growth without destroying such a cultural and natural heritage. This positive social environment is complemented by the existence of a continuous region of 650000 ha set within INR with good habitat, suitable prey availability, low conflicts, and regular presence of conservation agents to host an estimated population of 90 jaguars (De Angelo 2011).

It must be noted, however, that all this happens in a context where the jaguar is culturally present but ecologically absent. This situation enhances widespread support for the return of an ideal and symbolic animal that does not actually exist in the area. Public attitudes are highly dynamic and may rapidly change once jaguars become an actual presence in INR and its surroundings. This could stir actual or perceived conflicts of interest with neighbors and cattle ranchers, or increase the public perception of jaguars as cultural and tourist icons. Such changes in attitudes should be measured after jaguars are reintroduced to Iberá. It is within this changing landscape of values and attitudes that the managers of the species should base and adapt their future actions.

Acknowledgements. This study was partially funded by The Conservation Land Trust. We are indebted to A. Delgado and P. Díaz for their assessment of the first trial interviews, and to P. Pérez, M. Navarro, and G. Solís for their logistical support. S. Heinonen offered valuable advice during the whole process. M. Srur designed Fig. 1. F.C. thanks her family for all their support. We thank M. Di Bitteti, M. Altrichter, S. Marchini, and L. Hunter for reviewing previous drafts. N. Bunnefeld, M. Hayward, and an anonymous reviewer provided valuable comments.

\section{LITERATURE CITED}

Blanco JC, Cortés Y (2002) Ecología, censos, percepción y evolución del lobo en España: análisis de un conflicto. SECEM, Málaga

Caso A, Lopez-Gonzalez C, Payan E, Eizirik E and others (2012) Panthera onca. In: IUCN Red List of Threatened Species. Version 2011.2. www.iucnredlist.org (accessed 13 Sep 2013)

Chebez JC (2008) Los que se van. Fauna argentina amenazada Vol 3. Editorial Albatros, Buenos Aires

Clark JD (2009) Aspects and implications of bear reintroduction. In: Hayward MW, Somers MJ (eds) Reintroduction of top-order predators. Wiley-Blackwell, Chichester, p 126-143

CLT (The Conservation Land Trust) (2006) Esteros del Iberá. Importancia de su conservación. CLT, Buenos Aires

> Conforti V, Cascelli de Azevedo FC (2003) Local perceptions of jaguars (Panthera onca) and pumas (Puma concolor) in the Iguaçu National Park area, South Brazil. Biol Conserv 111:215-221

> Crawshaw J (2004) Depredation of domestic animals by large cats in Brazil. Hum Dimens Wildl 9:329-330

Crow JA (1992) The epic of Latin America, 4th edn. University of California Press, Los Angeles, CA

De Angelo C (2011) Evaluación de la aptitud del hábitat para la reintroducción del yaguareté en la cuenca del Iberá. Available at www.proyectoibera.org/download/ yaguarete/habitat_para_el_yaguarete_en_ibera.pdf (accessed 13 Sep 2013)

DEyC (Dirección de Estadística y Censos) (2011) Corrientes en cifras 2011. Dirección de Estadística y Censos, Provincia de Corrientes. Available at www.deyc-corrientes. gov.ar/files_provincias/920.pdf (accessed 13 Sep 2013)

Di Bitetti MS, De Angelo CD, Quiroga V, Altrichter M, Paviolo A, Cuyckens E, Perovic P (in press) Estado de conservación del jaguar en la Argentina. In: Medellín RA, Chávez C, de la Torre A, Zarza H, Ceballos G (eds) El jaguar en el siglo XXI: la perspectiva continental. Fondo de Cultura Económica, México 
Díaz GB, Ojeda RA (2000) Libro rojo de mamíferos amenazados de la Argentina. Sociedad Argentina para el Estudio de los Mamíferos, Buenos Aires

Dos Santos FR, Jácomo ATA, Silveira L (2008) Humans and jaguars in five Brazilian biomes: same country, different perceptions. Cat News 4(Spec Issue):21-25

EGES (Consultoría Integral en Gestión Pública) (2009) Provincia de Corrientes: informe de situación. Available at www.eges.com.ar

Foschiatti del Dell'Orto AMH, Bolsi AS (1993) La población de la Ciudad de Corrientes entre 1588 y 1988. Análisis desde la perspectiva geográfica. Rev Geogr 118:65-116

Gusset M, Maddock AH, Gunther GJ, Szykman M, Slotow R, Walters M, Somers MJ (2008) Conflicting human interests over the re-introduction of endangered wild dogs in South Africa. Biodivers Conserv 17:83-101

Hayward MW, Somers MJ (eds) (2009) Reintroduction of top-order predators. Wiley-Blackwell, Chichester

Jiménez I (2010) Restauración ecológica en el Iberá: el gran sueño. Aves Argentinas. Rev Nat Conserv 29:28-31

Jiménez I (2011) Reintroducciones de vertebrados en Argentina. Quercus 303:56-57

Jiménez Pérez I (1996) Limitaciones de la reintroducción y cría en cautiverio como herramientas de conservación. Vida Silv Neotrop 5:89-100

Jiménez Pérez I, Heinonen S (2011) El camino hacia la creación del mayor parque nacional de la Argentina en los esteros de Iberá. Proceedings of the 24th meeting of the Argentinean Mastozoological Society. SAREM, Buenos Aires, p 29

Johns D (2009) A new conservation politics: power, organization building, and effectiveness. John Wiley \& Sons, Oxford

Kaltenborn BP, Bjerke T, Strumse E (1998) Diverging attitudes towards predators: Do environmental beliefs play a part? Hum Ecol Rev 5:1-9

Kellert SR (1996) The value of life: biological diversity and human society. Island Press, Washington, DC

Kellert SR, Black M, Rush CR, Bath AJ (1996) Human culture and large carnivore conservation in North America. Conserv Biol 10:977-990

Kelly MJ, Silver S (2009) The suitability of the jaguar (Panthera onca) for reintroduction. In: Hayward MW, Somers MJ (eds) Reintroduction of top-order predators. WileyBlackwell, Chichester, p 187-205

Kleiman DG, Stanley Price MR, Beck BB (1994) Criteria for reintroductions. In: Olney PJS, Mace GM, Feistner ATC (eds) Creative conservation: interactive management of wild and captive animals. Chapman \& Hall, London, p 287-303

Kleiven J, Bjerke T, Kaltenborn BP (2004) Factors influencing the social acceptability of large carnivore behaviours. Biodivers Conserv 13:1647-1658

Kruuk H (2002) Hunter and hunted: relationships between carnivores and people. Cambridge University Press, Cambridge

Lindsey PA, Havemann CP, Lines R, Palazy L and others (2013) Determinants of persistence and tolerance of carnivores on Namibian ranches: implications for conservation on southern African private lands. PLoS ONE 8: e52458

Macdonald DW (2009) Lessons learnt and plans laid: seven awkward questions for the future of reintroductions. In: Hayward MW, Somers MJ (eds) Reintroduction of toporder predators. Wiley-Blackwell, Chichester, p 411-448
Maji A, Bath AJ (2010) Changes in attitudes toward wolves in Croatia. Biol Conserv 143:255-260

Maji A, Taussig de Bodonia AM, Huber D, Bunnefeld N (2011) Dynamics of public attitudes toward bears and the role of bear hunting in Croatia. Biol Conserv 144: 3018-3027

Mantilla M (1972) Crónica histórica de la Provincia de Corrientes. I.S.A.G., Buenos Aires

> Marchini S, Macdonald DW (2012) Predicting ranchers' intention to kill jaguars: case studies in Amazonia and Pantanal. Biol Conserv 147:213-221

Medellín RA, Equihua C, Chetkiewicz C, Rabinowitz A and others (eds) (2002) El jaguar en el nuevo milenio. Fondo de Cultura Económica, Universidad Nacional Autónoma de México \& Wildlife Conservation Society, México D.F.

Oli M, Taylor IR, Rogers ME (1994) Snow leopard (Panthera uncia) predation of livestock: an assessment of local perceptions in the Annapurna Conservation Area, Nepal. Biol Conserv 68:63-68

Palazón-Miñano S, Ruiz-Olmo J, Batet-Trías A, Jordana IA, Fernández-Rivera F (2011) Osos y humanos: del conflicto a la coexistencia. En Cataluña se trabaja con ganaderos y apicultores para prevenir daños. Quercus 304:24-31

Parera A (ed) (2004) Fauna de Iberá: composición, estado de conservación y propuestas de manejo. Fundación Biodiversidad Argentina, Buenos Aires. Available at http:// www.proyectoibera.org/download/vidasilvestre/fauna_ del_ibera.pdf (accessed 13 Sep 2013)

Paviolo AJ (2010) Densidad de yaguareté (Panthera onca) en la selva paranaense, su relación con la disponibilidad de presas, presión de caza y coexistencia con el puma (Puma concolor). PhD thesis, University of Córdoba

Pierce CL, Manfredo MJ, Vaske JJ (2001) Social science theories in wildlife management. In: Decker DJ, Brown TL, Siemer WF (eds) Human dimensions of wildlife management in North America. The Wildlife Society, Bethesda, $\mathrm{MD}, \mathrm{p}$ 39-56

Rabinowitz A (2005) Jaguars and livestock: living with the world's third largest cat. In: Woodroffe R, Thirgoog S, Rabinowitz A (eds) People and wildlife, conflict or coexistence? Cambridge University Press, Cambridge, p 278-285

Reading PR, Clark TW (1996) Carnivore introductions: an interdisciplinary examination. In: Gittleman JL, Funk SM, Macdonald DW, Wayne RK (eds) Carnivore behavior, ecology and evolution. Cornell University Press, Ithaca, NY, p 296-336

Smith DW, Bangs E (2009) Reintroduction of wolves to Yellowstone National Park: history, values and ecosystem restoration. In: Hayward MW, Somers MJ (eds) Reintroduction of top-order predators. Wiley-Blackwell, Chichester, p 92-125

Sokal R, Rohlf F (2000) Biometry: the principles and practice of statistics in biological research, 3rd edn. WH Freeman and Company, New York, NY

Williams CK, Ericsson G, Heberlein TA (2002) A quantitative summary of attitudes toward wolves and their reintroduction (1972-2000). Wildl Soc Bull 30:575-584

Zeiler H, Zedrosser A, Bath A (1999) Attitudes of Austrian hunters and Vienna residents toward bear and lynx in Austria. Ursus 11:193-200

Zimmermann A, Walpole MJ, Leader-Williams N (2005) Cattle ranchers' attitudes to conflicts with jaguar Panthera onca in the Pantanal of Brazil. Oryx 39:406-412 